\title{
Civil Proceedings in a Beleaguered Society
}

\author{
The Rt. Hon. Lord Lowry*
}

When looking for a subject for the Child \& Co Lecture, I thought it had better be one on which I could pose as some kind of authority. That narrowed the field considerably, but also made it a safer one in which to wander. Many people have already their own ideas about the Diplock Courts (where they got some of those ideas from I could not pretend to say), and I have had to express my ideas on them to two Lord Chancellors and seven Secretaries of State in the past fifteen years, so I felt that it might be wiser and more profitable this time to consider the impact of the "troubles", as they are euphemistically called, on civil proceedings in Northern Ireland. Inevitably many of the examples will be cases in which I have been involved. This reminded me in a salutary way of a remark made by a man who was my friend, the late Judge Conaghan, Q.C., when four of us, then relatively young junior counsel, were getting ready to have lunch one Friday: "And now", he said, "for another story of which I am the hero." That, I am afraid, accurately describes, unless one is very careful, about ninety per cent of legal - and golfing reminiscences; therefore I must be careful. Sir John Ross, the last Lord Chancellor of Ireland, published one book of reminiscences and threatened another. There was an unaccountable delay, but the Attorney-General, Denis Henry (who was our first Lord Chief Justice), thought of the solution. "I am told", he said, "that the compositor has run out of capital I's."

Neither I nor my brethren, much as I admire them all, are the heroes of this story. I am confident that our judicial brethren in England and Wales and in Scotland would cope equally well with our unusual problems if called upon. My object is simply to show how the Courts have reacted to an extraordinary situation. For nearly eighteen years the Queen's Peace itself has had to meet in a part of her Kingdom a vigorous and continuous challenge, and the Queen's justice has had to be administered during that time without fear or favour.

In such circumstances the rule of law is under threat. In a civil war situation Cicero proclaimed, "inter arma silent leges." As the trial judge in R. v. Gibney and others ${ }^{1}$ I remembered this and said:

* Lord Chief Justice of Northern Ireland. The Child \& Co London Lecture 1987, delivered in the Inns of Court School of Law and reprinted by kind permission of Lord Lowry and Child \& Co..

1. [1983] 13 N.I.J.B. 
"'Amid the clash of arms the laws are silent': so Cicero exclaimed over 2000 years ago. During the greatest conflict of our history Lord Atkin ${ }^{2}$ bravely ventured to contradict this assertion. Now, too, peace, order and society itself are under fierce and constant attack and that is why we must remember Lord Atkin's famous dictum; 'In this country, amid the clash of arms the laws are not silent. They may be changed, but they speak the same language in war as in peace'."

I continued:

"This war is being waged by organisations which style themselves armies and observe military procedures, but it has not invaded, and will not be allowed to invade, the courts. The rule of law has prevailed and will continue to prevail there. We will accept but one standard of proof in criminal cases, namely, proof beyond reasonable doubt. This is a concept difficult enough to describe, but easy for an honest man to recognise, which brings to criminal adjudication, whether by a jury or by another tribunal, a certainty and a finality which can be absent from civil proceedings.

It is a statement of the obvious that maintaining the rule of law means deciding cases according to law, and the paramount law in criminal cases is that guilt cannot be established save by proof beyond reasonable doubt."

You may recall that toward the end of 1971 , as a result of complaints in Northern Ireland, a committee of Privy Counsellors was appointed to consider "whether, and if so in what respects, the procedures currently authorised for the interrogation of persons suspected of terrorism and for their custody while subject to interrogation require amendment." Lord Gardiner, famous as a champion of the rule of law, submitted a minority report in which he stated that unauthorised procedures of interrogation had been used which were illegal and would continue to be so unless the law was amended, pointing out at the same time that it was not unnatural for the Royal Ulster Constabulary, who had used the procedures, to assume that the Army had satisfied themselves that the procedures which they were training the police to employ were legal. I do not need to discuss the Report, ${ }^{3}$ which was submitted on 31 st January, 1972, but I have been struck by the coincidence with my judgment in $R$. v. Gibney inherent in the words used by Lord Gardiner at paragraph 12 , p.15:

"The situation in Northern Ireland is one in which members of the Irish Republican Army are conducting a campaign of terror which includes brutal murder, arson, the use of explosives against innocent men, women and children and outrages of all kinds. There is virtually a war going on between

2. In Liversidge v. Anderson [1942] A.C. 206, at p.244.

3. Cmnd. 4901. 
the Government of Northern Ireland and the Irish Republican Army and in this conflict the lives, not only of innocent civilians but of the police and army, are at stake in circumstances of appalling difficulty for the members of those forces whose courage, resolution and behaviour are all so well known."

The comparison between Lord Gardiner's clear perception of the crisis and his ultimate opinion of the methods used to meet it is, I submit, based on the rule of law, which is the mark of a civilised society. That rule involves a respect for impartial justice. It protects the weak against the strong and the individual against the state. It is most at risk, and therefore most in need of protection, when the state itself is in danger. You may ask whether the rule of law ought to be upheld at the risk of the safety of the realm. My answer is, first, that the judges are sworn and obliged to judge according to law. If doing that truly endangers the state, then the law must be changed. But conflict between the rule of law and the public good is more apparent than real. A heavy price can be paid, in terms of stability, if the State itself, through its judges, spurns the rule of law.

When I turned to the Northerm Ireland Law Reports and the Northern Ireland fudgments Bulletin (the latter founded on an idea which my predecessor, Lord MacDermott, imported from Cyprus), I was surprised by the number of cases which can be said to arise from the troubles. I shall have to be selective, dividing the subject and picking a few examples. I really cannot in the space available afford a consideration of all the interesting legal points arising from these cases.

I plan to look first at actions by individuals against the Executive for false imprisonment, assault and similar torts, then at claims for compensation for criminal injuries to the person and to property. Next I shall notice the impact of emergency powers, apart from criminal trials. After that, I shall invite you to look at experience in prison, both disciplinary and administrative, and will pass from there to the political - mainly local government - scene. After that I wish to say something about judicial review, which has been widely resorted to, as you will presently find out. And finally, I shall try to extract some general conclusions from what I have said.

My division of topics is arbitrary. There must be overlapping. And, lest you should suppose that the Courts are mainly concerned with the kind of cases I am going to talk about, it may be no harm to state that personal injury claims are still the main diet of the Queen's Bench Division and that the county court, Chancery and Family Division business continues with ever-increasing volume, to say nothing about ordinary criminal work, in the volume of which hitherto we have not yet caught up with the mainland.

I would first explain that we have three Lords Justices and six puisne judges, as well as myself, in the Supreme Court. Each is available for every kind of work in addition to his first commitment and all sit in the Crown Court. There are thirteen county court judges. Of these one is Chief Social Security Commissioner, another is President of Industrial Tribunals and a third is President of the Lands Tribunal. 
As well as exercising civil jurisdiction at first instance, they hear appeals from magistrates and in that capacity are subject to judicial review and to appeal by case stated. They are also judges of the Crown Court and, in accordance with my directions given with the authority of the Lord Chancellor, try all kinds of offences except murder. There are seventeen Resident Magistrates and a number of Deputies. All are barristers or solicitors, like stipendiaries in this jurisdiction.

\section{Actions against the executive}

I deal here mainly with claims for false imprisonment and assault, including trespass to the person by shooting, in proceedings commenced by writ of summons or in the county court by civil bill. In the High Court the plaintiffs are under our law (s. 62 (1)(d) and (e) of the Judicature (Northern Ireland) Act 1978 and its predecessor, the Act of 1877) still entitled to a jury, but they have set down nearly all the cases for trial by a judge alone, which some people may regard as an interesting commentary on the judge-alone Diplock Courts. The facts in these cases, often complex and hotly disputed, as well as the legal issues and, where appropriate, the amount of damages and the question whether aggravated or exemplary damages should be awarded, have therefore by consent almost always been entrusted to the determination of a judge.

There are all kinds of action. Let me give you one example, Walsh v. Ministy of Defence. ${ }^{4}$ It involved no legal points and was a case of mistaken identity. The plaintiff, a young schoolteacher, was arrested by the Army at 6.30 a.m. at home, taken to a police station, where she was kept for two hours. She was released when it seemed that a mistake had been made, but received no explanation, reassurance or apology and she sued for damages alleging that she was

"unlawfully detained and kept against her will in degrading circumstances, where she was assaulted, subject to trespass on her person, humiliated, degraded and wrongfully and falsely imprisoned."

As I said in my judgment, this was in technical language an accurate description. The defence denying the unlawfulness of the arrest was persisted in up to the morning of the trial and then abandoned. Having set out the facts and my comments, and having referred to Rookes v. Barnard ${ }^{5}$ and to a decision by Kelly L. J. in a similar case, Lavery v. Ministry of Defence, ${ }^{6}$ I concluded:

"The conduct of the defendant's agents at the briefing (and, by unavoidable inference, before it) renders the defendant liable to pay exemplary damages under Lord Devlin's first common law heading for oppressive and arbitrary action by the servants of the Government. I wish to make it clear that there is no evidence that Private Moran or any other soldier in the patrol behaved badly or that anything gratuitously oppressive was done at Springfield Road: 
the fault, and it was a grievous fault which infringed the liberty of an innocent subject, lay with higher authority."

I awarded $£ 4,000$, to include exemplary damages. Recently, in Hamilton v. Chief Constable ${ }^{7}$ Hutton J. awarded $£ 4,000$ for an assault in a police station. The case required disputed facts to be elucidated and the judge concluded:

"There is nothing in the present case to suggest that the assault by the constable was sanctioned or connived at by any police officer senior to him, but the judgment of Kelly L. J. in Lavery v. Ministry of Defence makes it clear that exemplary damages can be awarded against the body or person vicariously liable under common law or statute for an isolated and unsanctioned assault carried out by a soldier or police officer of junior rank, where the nature of the assault and the surrounding circumstances are such that the Court considers that exemplary damages should be awarded."

Many other allegedly similar cases, I should add, have been decided in favour of the defendants.

There are two important cases in which the Ministry of Defence was sued. In Farrell $\mathrm{v}$. Ministy of Defence ${ }^{8}$ the Army got wind of what was believed to be a plan to blow up a bank in Newry. They posted snipers on rooftops with a view of the Bank. Three men approached the Bank and looked to be trying to rob two men who were putting a money bag in the night safe. The soldiers gave evidence that they challenged the three men, who ran away; they then opened fire and killed the three men. Their right to shoot depended on section 3(1) of the Criminal Law Act (Northern Ireland) 1967, which is identical with the corresponding provision in force in England:

" 3 (1) A person may use such force as is reasonable in the circumstances in the prevention of crime, or in effecting or assisting in the lawful arrest of offenders or suspected offenders or of persons unlawfully at large."

The widow (by then Mrs Farrell) of one of the deceased (named McLaughlin) sued the Ministry for damages and the case was tried with a jury which was asked, and answered, questions as follows:

"1. Did the soldiers fire because soldier A suspected with reasonable cause -

(a) that the husband of the plaintiff and two other men had attempted to place an explosive bomb or an incendiary device in or at the Provincial Bank, and

(b) that such explosive bomb or incendiary device would endanger life?
Answer: (a) YES
(b) YES

7. 1986 unreported.

8. [1980] N.I. 55. 
2. If the answer to questions $1(a)$ and 1(b) is 'Yes', was it reasonable in the circumstances (including the reasonable suspicion of soldier A) in the prevention of crime for the soldiers to fire to kill:

Answer: YES

3. If the answer to questions $1(\mathrm{a})$ and $1(\mathrm{~b})$ is 'Yes', was it reasonable in the circumstances (including the reasonable suspicion of soldier A) in effecting the lawful arrest of the three men for the soldiers to fire to kill?

Answer: YES

4. Did the soldiers fire after Soldier A had twice shouted at the three men to halt?

Answer: YES

5. When the barman $\mathrm{Mr}$ O'Neill was at the night safe in the front wall of the Provincial Bank did the husband of the plaintiff and two other men attempt to rob him of the money he was going to place in the night safe?

Answer: YES

6. Was the shooting entirely out of proportion to the occasion?

Answer: NO

7. Was there fault on the part of the husband of the plaintiff which contributed to his death?

Answer: YES

8. If answers to questions 2 and 3 are 'No' and answer to question 7 is 'Yes', what percentage reduction should be made in the damages having regard to the responsibility of the plaintiff's husband for his own death?

Not answered (\% reduction)."

The effect of the answers was a verdict for the defendant and the plaintiff appealed. We ordered a new trial, being dissatisfied with the form of the questions and certain parts of the judge's charge, but the Ministry appealed to the House of Lords, which restored the verdict. Having regard to the pleadings and the course of the trial, it does appear that we were wrong to lay so much stress on the need to consider the question of negligent planning, which made it inevitable that escaping men could not be stopped except by shooting them. Looking back, I think that our fault was to make a better case for the plaintiff than she made herself - a dangerous course, having regard to the duty of the plaintiff to give the defendant notice of her case. I therefore recognise the force of Viscount Dilhorne's observations on this part of the appeal. Because it was a jury trial, there were available no findings of fact, and this did not help the plaintiff. Counsel for the 
Ministry conceded at the trial that the soldiers would not have been entitled to shoot if their object was to prevent the escape of attempted robbers. Although she had lost, Mrs Farrell found a means of taking the Government to Strasbourg, where they agreed to pay her quite a lot of money.

Lynch v. Ministry of Defence, ${ }^{9}$ tried by Hutton J. without a jury, was a more clearcut case on the facts and the law, which was again section 3(1) of the 1967 Act. The plaintiff, driving a car at night in Belfast, failed to obey a soldier's red light signal to stop. He was fired on and hit, crashed his car, was badly injured and sued the Ministry. The defendant in these circumstances had to justify the act of firing, and the learned trial judge, although he rejected the reasonableness of shooting to effect an arrest, accepted that the soldiers in firing were using reasonable force in the prevention of crime. He therefore found against the plaintiff and the judgment was not appealed. The outline facts were agreed but all the other facts were disputed. Two points are noteworthy. First, criminal cases from Northern Ireland were referred to, in which section 3(1) had been canvassed, including the decision of the House of Lords in Attomey-General for Northern Ireland's Reference. ${ }^{10}$ Secondly, the passages which the learned trial judge cited at page 229 from the speech of Lord Diplock and from the judgment of Jones L. J. in The Attorney-General's Reference and at page 230 from my judgment in an attempted murder case, $R$. v. McNaughton, ${ }^{11}$ tend to show that the crime which is to be prevented need not be imminent in order to make the shooting reasonable.

Some cases where false imprisonment was alleged made necessary the interpretation of the enabling statute. An example is McKee v. Chief Constable for Northern Ireland, ${ }^{12}$ where the House of Lords, reversing a majority decision of the Court of Appeal, restored the judgment of the trial judge (MacDermott J.) and held that the power to "arrest without warrant any person whom he suspects of being a terrorist" means that a constable makes a lawful arrest if he has an honest, though not necessarily a reasonable, suspicion that the person arrested is a terrorist. The House approved the interpretation by McGonigal J. of a special powers regulation in In re McElduff, ${ }^{13}$ a habeas corpus application in which the arrest was held invalid for other reasons.

The remedy of habeas corpus has been freely resorted to. I refer to In re Close, ${ }^{14}$ In re Murphy ${ }^{15}$ (where O'Donnell J. held detention of young persons to be lawful but stated that they ought to have conditions no less favourable than those of convicted young persons serving a sentence) and Ex Parte Lynch, ${ }^{16}$ where I held that the treatment and conditions of detention accorded to a person lawfully

9. [1983] N.I. 216.

10. [1976] N.I. 169; [1977] A.C. 105.

11. [1975] N.I. 203.

12. [1985] 1 Al1 E.R. 1.

13. [1972] N.I. 1.

14. [1972] N.I. 27

15. [1973] N.I.J.B. Nov.

16. $[1980]$ N.I. 126. 
detained do not touch on the lawfulness of that detention and do not therefore give rise to the remedy of habeas corpus.

One of the most interesting habeas corpus applications was Quigley v. Chief Constable, RUC, ${ }^{17}$ where the sister of Linda Quigley, whose husband was due to give evidence as an accomplice (or "supergrass") against several accused charged with terrorist offences, applied for a writ of habeas corpus directed to the Chief Constable to produce Linda Quigley before the Queen's Bench Division of the High Court. She had disappeared with her husband and children from their home in Londonderry and later appeared at Londonderry Recorder's Court to pursue a civil claim of her own. Her solicitor deposed that Mrs Quigley consulted with him before court in a place guarded by police and that she expressed a wish to meet relatives who were at the courthouse, but that at the end of the case she left with the police. The respondent's affidavit stated that Mr Quigley had been taken to a place of safety because terrorists were looking for him, that Mrs Quigley had gone with him voluntarily, but, while this might well be right, the Court considered that a prima facie inference of restraint on Mrs Quigley existed. The next stage is described in In re Quigley. ${ }^{18}$ The respondents made a return to the writ stating that Mrs Quigley was living with her husband and children and that they were receiving police protection by their own wish. "She was free to go where she wished", and the respondents could not therefore produce her body. The applicant sought to impeach the return, alleged contempt of court and cited section 3 of the Habeas Corpus Act 1816. The court held the return good but inquired in accordance with section 3, and then heard Mrs Quigley in Chambers. Sitting finally in open court again, Hutton J. declared that the facts set forth in the Chief Constable's returns were true and concluded: ${ }^{19}$

"After having appeared before me in Chambers Mrs Quigley had a meeting with her sister and other relatives here in the Royal Courts of Justice, and at her own wish she is going to rejoin her husband and children."

\section{Criminal injuries}

Criminal injury claims for injury to the person and damage to property have been known to the Irish Courts since 1836. The cost of a successful claim was once borne by county and district rates and now falls on central funds, which is particularly logical where terrorism is concerned. The claim is made to the Secretary of State, from whom there is an appeal to the county court and thence to the High Court. A case can be stated by either court to the Court of Appeal on a point of law. The relevant statutes lay down the form and time for application and embody restrictions on the right to recover which are dictated by the terrorist background. Someone who has been involved in terrorism cannot recover; a

17. [1983] N.I. 238.

18. [1983] N.I. 245.

19. P.257. 
requisite condition is that full disclosure of facts known to the applicant is made in his application; and, even after an award is made (either by himself or by a court), the Secretary of State can withhold all or part of the compensation pending the answers to such reasonable requests (and the reasonableness of a request is justiciable) as the Secretary of State may make for further information.

The Reports are full of these cases and you can imagine the questions of law and fact which must be resolved in order to see what the statutory provisions mean and whether they apply. Authorities in the law of tort are called in aid on questions of causation and damages, and decisions in criminal injury cases are in their turn applied in the field of tort. Not wishing to venture beyond this brief outline, I shall mention only one case, in which the Court of Appeal adjourned a case stated in $O^{\prime}$ Dowd $\mathrm{v}$. Secretay of State ${ }^{20}$ until the House of Lords had given its decision in McLoughlin v. O'Brian. ${ }^{21}$ This enabled us to decide with confidence in favour of the applicants, who had suffered nervous shock when three close relatives were murdered and another was wounded in a shooting incident, and the applicants had arrived on the scene shortly afterwards. As well as being concerned with nervous shock, we had to consider the meaning of the words "directly attributable", and the case is a good example of the interaction between tort and criminal injury cases. Having derived much assistance in $O^{\prime}$ Domd from McGregor v. The Board of Agriculture for Scotland, ${ }^{22}$ I cannot resist saying how much more help we could obtain from the Session Cases, had we the time and the industry to look more often in that direction.

\section{Emergency powers}

I shall treat emergency powers by referring to three cases under the Civil Authorities (Special Powers) Act (Northern Ireland) 1922. The first, R. (Hume) v. Londondery $\mathfrak{F} .{ }^{23}$ is of some legal and historical interest and I regard it as an example of a collision between the rule of law and the apparent safety of the State (not by reason of its own facts but because of the wide effect of a decision against the executive). The case took the form of an application to the Divisional Court for an order of certiorari to quash a conviction by the magistrate for infringing a regulation under the Special Powers Act, as I shall call it, which made it an offence for a person in a group of three or more persons not to disperse when ordered to do so by, among others, a member of Her Majesty's Forces. The main ground for seeking to quash the conviction relied on the fact that, unlike the Parliament of the United Kingdom, the Northern Ireland Parliament operated under what could be called a written constitution, consisting of sections 4 and 5 of the Government of Ireland Act 1920, with the result that it was possible for an Act of Parliament to be ultra vires; a regulation could also be ultra vires, not only for being outside the

20. [1982] N.I. 210

21. [1983] 1 A.C. 410.

22. [1925] S.C. 613 .

23. [1972] N.I. 19. 
scope of its parent Act, but also for inconsistency with sections 4 and 5 of the 1920 Act. The defendants were the well-known politican, $\mathrm{Mr}$ John Hume, and four other members of the SDLP who, it seems, had decided to test the validity of the unpopular Special Powers Regulations by sitting on the footpath and refusing to be moved on by the Army. The point of the case was that Regulation 38 conferred certain powers on members of the armed forces, whereas section 4 of the $1920 \mathrm{Act}$ forbade the Northern Ireland Parliament to make a law "in respect of" what were called reserved matters, such as the Crown, taxes, foreign relations and "the navy, the army, the air force etc. etc.".

In the circumstances prevailing then and since this challenge raised a much more serious issue than the right of a soldier to move on a small group of people who were doing no real harm, because there were in existence other special powers regulations which gave soldiers a power to stop and search at roadblocks and elsewhere and also a power of arrest, which had been exercised many times already. With the activities of the IRA at full blast, the whole security system was at risk. The result turned on the interpretation of the words "in respect of", and Crown counsel, now Carswell J., exercised his considerable intellect and ingenuity in a vain effort to put a gloss on the ordinary meaning of that phrase. We held the regulation to be ultra vires and quashed the conviction. As soon as we had given judgment, the Northern Ireland Act 1972 went through all its stages in both Houses at Westminster in one day, declaring the Parliament of Northern Ireland to have, and always to have had, power to make regulations of this kind. The Court did not resent this, nor, I believe, could anyone else: it was a proper remedial exercise, since there was in the regulations nothing to object to except their invalidity. The legislation was frankly, but necessarily, retrospective. Merely to confer immunity for past acts would not have been enough. Therefore, when in $R$. v. Gorman ${ }^{24}$ a man who had been arrested under Special Powers Regulation 11 was charged with escaping from lawful custody, as the trial judge I held that regulation to be valid in spite of Hume's case and because of the validating 1972 Act; the rule of law does not invariably side with the citizen.

My second example of emergency powers is $R$. (Secretary of State) v. Recorder of Belfast, ${ }^{25}$ which raised the question whether various orders made by the Minister of Home Affairs between October 1969 and October 1970 obliging the owners of licensed premises to close were "acts ... involving interference with private rights of property". If so, compensation was payable under section 11(1) of the Special Powers Act. If not, the owners contended, the orders were invalid because the restriction on opening hours amounted to a "taking" of their property contrary to the general prohibition against taking property without compensation in section 5 of the 1920 Act.

The Recorder of Belfast held in favour of the owners and ordered an arbitration but the Court of Appeal, affirming Gibson J., held that the word "act" in section

24. [1974] N.I. 152.

25. [1973] N.I. 112. 
11(1) applied only to physical steps and not to an order. We further held that the restriction on opening was not a taking within the meaning of section 5 . The case was a difficult one and splendidly argued, and I was both surprised and sorry that the large, and presumably wealthy, body of owners did not appeal to the House of Lords.

I feel that the loser in my third emergency powers case was most unfortunate. It was $R$. (McCreesh) v. County Court Fudge for Armagh, ${ }^{26}$ in which the applicant owned a garage and service station in Newtownhamilton which catered for heavy goods vehicles on a main route between the Republic of Ireland and Great Britain via the port of Larne. The Army erected security barriers on all streets into Newtownhamilton so that passing traffic was diverted, but the applicant still had access from his premises to the street. The applicant claimed compensation under section 25(1) of the Northern Ireland (Emergency Provision) Act 1973, which was the successor to section 11(1) of the Special Powers Act, but in the Court of Appeal, reversing Gibson L. J., who had reversed the county court judge (Judge Babington Q.C.), we held that, although the applicant had a special and individual interest in the public right to the relevant part of the highway and would, apart from statute, be entitled to sue for damages, yet there was no interference with his private right of direct access to the highway, and therefore there was no right to compensation under section 25(1).

\section{Prisons: disciplinary and administrative aspects.}

Looking first at the disciplinary side, it is generally accepted that judicial review will lie to a Board of Visitors. A number of prisoners have contended that they are entitled to legal representation at a Board hearing absolutely, and not just at the Board's discretion according to the criteria in Ex parte Tarrant, ${ }^{27}$ a decision of the Divisional Court which we have followed with no misgivings. Indeed the Convention on Human Rights seems to point the same way. Article 6(3) provides:

"Every person charged with a criminal offence has the following minimum rights -

(c) to defend himself in person or through legal assistance of his own choosing or, if he has not sufficient means to pay for legal assistance, to be given it free when the interests of justice require."

The House of Lords has in In re Hone ${ }^{28}$ given leave to appeal from our Court of Appeal on this question of absolute right and we shall all await the outcome with interest.

I enjoyed reading the whole of Sir Patrick Neill's lecture ${ }^{29}$ and in particular I was cheered by his joining issue on page 7 with your Court of Appeal's decision in

26. [1978] N.I. 164.

27. [1984] 1 A11 E.R. 799.

28. 1986 unreported.

29. The Child \& Co Lecture, 1985. 
R. v. Deputy Governor of Camphill Prison, ex parte King ${ }^{30}$ to the effect that a Prison Governor's award cannot be the subject of judicial review. Our Court of Appeal, although mindful of the respect which we always entertain for the decisions of your Court of Appeal, went the other way in In re McKieman, ${ }^{31}$ much attracted by the observations of Kerr L. J. in the Divisional Court, but not then aware of the view which Sir Patrick had expressed in his lecture. I understand that Ex parte Leech (unreported) will provide an opportunity for the House of Lords to consider the question.

On the administrative side, we have come across a few attempts to query by judicial review executive decisions by the Governor and have also had an application $^{32}$ to quash an order by the Secretary of State forbidding $\mathrm{Mr}$ McCartney, who is serving a sentence of life imprisonment for a terrorist offence, to receive a visit from an elected Sinn Fein Councillor.

I heard and refused the application and in doing so made an observation the bearing of which may be appreciated when I pass to the political cases:

"It is natural to ask why the respondent's decision should be deemed reasonable when this Court has held that members of local authorities cannot lawfully take steps to prevent Sinn Fein councillors from participating in local government business. The difference is that Sinn Fein councillors are, in the present state of the law, entitled as individuals to take their seats and that the other members of the council have no legal power to prevent them from doing so, whereas the respondent here has a right under Rule 58(1) to regulate visits to prisoners according to the discretion conferred on him by that rule, so long as the discretion is reasonably exercised within the meaning of the Wednesbury case. The anomaly is explained by the absence of a statutory power in the one case and its presence in the other."

\section{Politics and local government}

Sinn Fein is taken to be the political wing of the IRA and accordingly the presence of its members on elected bodies has been greatly resented. This has caused Unionist councillors to try to exclude from the work of the council Sinn Fein councillors by appointing a special committee consisting of all the members of the Council, except the two Sinn Fein members, to deal with all the Council's functions, with the exception of making a rate, borrowing money and acquiring, holding or disposing of land, being the matters expressly excepted by statute from the powers of a committee.

Hutton J. held, with the aid of authority, that he could take judicial notice of the policy and aims of Sinn Fein. ${ }^{33}$ He continued:

30. [1985] Q.B. 735.

31. [1985] 6 N.I.J.B. 6.

32. In re Pius McCarney, 1986 unreported.

33. [1985] 7 N.I.J.B. 22. 
"Therefore I take judicial notice of the facts that the policy and aims of Sinn Fein are to take power in Northern Ireland with a ballot paper in one hand and an Armalite in the other, that Sinn Fein gives unambivalent support to the 'armed struggle', which is the euphemism used by Sinn Fein to describe terrorist murders and other violent crimes committed by the Provisional IRA, and that when the elected representatives of Sinn Fein take part in the normal work of an elected council this is just one plank of their policy, the other plank being the unambivalent support of murder and other acts of terrorist violence committed to overthrow democratic government in Northern Ireland."

Then, having considered all the resolutions aimed at excluding Sinn Fein from the Council's deliberations and finding that they complied with the test of reasonableness posed by Associated Provincial Picture Houses Ltd. v. Wednesbury Corporation, ${ }^{34}$ and also having noted an elected assembly's power to protect itself, as described by the Earl of Selborne in Barton v. Taylor, ${ }^{35}$ he concluded that the Council had no power to exclude members by reason of the objects of their organisation and that the resolution to appoint a committee was ultra vires because the statutory power to do so could not validly be exercised for a purpose other than that for which the power was created. In the course of his judgment he said (at p.45):

"I consider that the decision whether or not members of Sinn Fein should be prevented from sitting as councillors, because it is the policy of Sinn Fein to support terrorist murder and violence, gives rise to an issue of great general importance and is a decision to be made by the Government and Parliament and not by individual councils. I am confirmed in this opinion by the consideration that, if an individual council has powers by a majority vote to exclude Sinn Fein councillors, it appears that, depending upon the strength of the various political parties in the individual council chambers, Sinn Fein councillors would be excluded from some councils in Northern Ireland but not from others."

Carswell J. had to pronounce on a further effort by Craigavon Council in In re French and Other' Application. ${ }^{36}$ The Unionists hit on the idea of requiring a declaration against violence as a prerequisite of sitting on the Council, but this offended against the plain words of section 21(1) of the Northern Ireland Constitution Act 1973 which, as the Council argued and as the judge recognised, was enacted for a very different purpose. Again, Carswell J. considered that the challenged resolutions would have passed the Wednesbury test, if that had been the problem. He made this observation: ${ }^{37}$

34. [1948] 1 K.B. 223.

35. (1886) 11 A.C. 197, 203.

36. [1985] 7 N.I.J.B. 48.

37. Ibid., p.68. 
"I feel that I should state in conclusion that is has been my concern throughout this matter, sitting as a court of law, to deal purely with the legal issues arising from it. I can only declare and apply the law as in my judgment it presently stands, whether that state of the law may be regarded by any section of the population as satisfactory or deficient. I do not propose to express any opinion on whether the law should be amended. That is within the domain of Parliament and Her Majesty's Government, and I do not wish to be taken to express or indicate any views upon such a matter."

In In the Application of Christopher Neeson ${ }^{38}$ the Court of Appeal approved the reasoning in Curran's case and French's case and, for similar reasons, was obliged to hold bad a new idea, which was to create four different committees, each comprising all the Council members except Sinn Fein. Carswell J., having quoted the description of Sinn Fein which I reproduced above, went on in French's case:

"Notwithstanding these facts which are, in my view, undeniable and universally known, Sinn Fein has been permitted to operate as a political party without being proscribed, and that being so, it has to be regarded by the law as a legitimate political party whose members are legally entitled to stand for election and take their seats as Councillors."

In the Court of Appeal I put it another way:

"Like Carswell J. I adopt what Hutton J. said in Curran's case, but I do not subscribe to the view that $\operatorname{Sin} n$ Fein has to be regarded as a lawful organisation (or by necessary implication as a 'legitimate political party') just because it has been allowed since 1975 to operate as a political party without being proscribed. That is a different thing from saying, in the present state of the law, that individual members of Sinn Fein, if not otherwise disqualified, cannot legally stand for election and take their seats as councillors, if elected; but they are entitled to do so despite their membership of Sinn Fein and not because of it."

One can see from these cases, and also appreciate, the difference in the result from that obtained in relation to the administrative ban on prison visiting.

The Unionist protest against the Hillsborough Agreement signed on 15th November, 1985 ("the Anglo-Irish Agreement") has also involved the Courts. Belfast City Council, as a protest, adopted a policy of adjourning its meetings and by resolution delegated all its functions (except three which there was no power to delegate) to the Town Clerk. Mr Cook, an Alliance Councillor, obtained from Hutton J. a declaration that the Council's resolutions were unlawful and an order of mandamus to compel the Council to resume normal working: In re Cook and others' application. ${ }^{39}$ The Court of Appeal affirmed the relief thus granted and,

38. 1986 unreported.

39. [1986] 1 N.I.J.B. 43 and 89. 
when the Council did not comply, the applicant issued contempt proceedings which resulted in the Council's being fined $£ 25,000$. Similar proceedings regarding other district councils have reached various stages of development and it would not be right for me to comment on pending litigation. As Hutton J. observed when dealing with applications against a number of councils:

"The resolutions were passed as part of the political protest against the Anglo-Irish Agreement. This court is in no way concerned with the suggested merits or demerits of the Anglo-Irish Agreement; the Court is only concerned to decide the issue whether or not the resolutions which are now challenged by the applicants are lawful or unlawful. As the learned Lord Chief Justice stated in delivering the judgment of the Court of Appeal in Cook's case at p.103, it is the duty of the Court 'to decide the point at issue according to law and without fear or favour, affection or ill-will'."

The learned judge also recalled other observations which I made in that case (at pp.92-3):

"What, however, the Council is not entitled to do is to refuse or deliberately neglect to discharge its statutory obligations as the elected local authority for the Belfast District and thereby to deprive the ratepayers and citizens of Belfast of the Council's services. Nor is it entitled to carry out development in the shape of the banner (which is an advertisement within the meaning of the Planning (Control of Advertisements) Regulations (Northern Ireland) 1973) without first having obtained planning permission. These are the unlawful acts of which the applicants have complained.

It is clear that the real dominant purpose of the majority of the Council in passing and implementing the resolutions complained of was to oppose the Anglo-Irish Agreement but, however legitimate a political objective this is thought to be, its legitimacy could not justify or validate the unlawful conduct to which we have referred, and the object of the majority of the Council (or even hypothetically of the entire Council) cannot with impunity be pursued by the unlawful means which the Council, by a majority, has chosen to adopt ...

The Council's decision was from the local government standpoint, and we emphasise those words, (the local government standpoint) the negation of all the principles according to which local government is carried on through discussion and debate among elected representatives, culminating in decisions on a wide variety of important matters. To say this is not to call in question the ability of the Town Clerk; but to leave all these matters to a paid official, no matter how competent, is simply not the way to carry on local government. It is in fact completely unreasonable in the Wednesbury sense and (we emphasise these words again) in the local government context.

As for this step being a way of pursuing a lawful object we hold that it is a wholly unreasonable and therefore unlawful means of pursuing that object, 
since it undermines the accepted principles of local government in the way that we have pointed out. To put forward section 129 as a shield against the accusation of Wednesbury unreasonableness does not prevent the decision to refrain from activity and to delegate everything to the Town Clerk which could lawfully be delegated from being unreasonable. It is the activity of the elected representatives which is the essence of local government, as distinct from giving the whole matter into the hands of the Town Clerk to make all the decisions and transact all the busines of which he is legally capable."

I do not have to emphasise the wide extent of the discretion which the court is obliged to exercise when it comes to the question of enforcement and considers the impact of its orders on individual councillors.

\section{Judicial review - general points}

You will have noticed the liberal resort which parties have had to judicial review in order to attain their object of challenging all kinds of decisions and adjudications. The same thing has happened in England and I am prompted to make a few general points.

You will recall that in $R$. v. Northumberland Compensation Appeal Tribunal, exparte $S h a{ }^{40}$ the Divisional Court and the Court of Appeal rediscovered the weapon of quashing a decision for error of law on the face of the record (and not simply for excess or absence of jurisdiction). This was a weapon the existence of which had been denied by a very distinguished Court of Appeal in Racecourse Betting Control Board v. Secretary of State for Air. ${ }^{41}$ In $R$. v. Cromn Count for Knightsbridge ${ }^{42}$ Griffiths L. J. again emphasised that for over a hundred years the use of certiorari to quash a decision for error of law on the face of the record fell into disuse, pointing out that, so far as criminal jurisdiction was concerned, this could be largely attributed to the short form of conviction introduced by the Summary Jurisdiction Act, 1848. The Northumberland case came as a surprise to the Bench and Bar in Ireland, both North and South, since the weapon referred to had never become rusty, but continued to be wielded vigorously throughout the period in question. Our bible on certiorari was R. (Martin) v. Mahony ${ }^{44}$ in which Gibson J., a master of the common law, said: ${ }^{.4}$

"Certiorari lies (a) where there is want or excess of jurisdiction when the inquiry begins or during its progress; (b) when in the exercise of jurisdiction there is error on the face of the adjudication; (c) where there has been abuse of jurisdiction (as by mis-stating the complaint, $\mathfrak{E}_{\text {c., }}$, or disregard of the essentials of justice and the conditions regulating the functions and duty of

40. [1951] 1 K.B. 711; [1952] 1 K.B. 338.

41. [1944] Ch. 114.

42. [1982] Q.B. 304

43. [1910] 2 I.R. 695 .

44. Ibid., at p.731. 
the tribunal); (d) where the Court is shown to be disqualified by likelihood of bias or by interest; (e) where there is fraud."

The case is one of historical interest, because Lord O'Brien L.C.J. took the opportunity to assemble a Divisional Court of eight judges in order to extirpate the heresy committed by Palles C.B., (sitting in the Exchequer Division in 1888 and differing from a decision of the Queen's Bench Division on the same point in the same case two days earlier) when he ruled that, notwithstanding the refusal of certiorari to quash a conviction for lack of evidence, habeas corpus would issue to release the convicted prisoner. We have long memories in Ireland - and not only in politics.

But the Northumberland case did not introduce the revolution. That happened in 1977 when a procedure known as judicial review was introduced by Order 53. For the first time all or any of the remedies of certiorari, mandamus, prohibition, a declaration and damages could be claimed together in proceedings on the Crown side; interrogations could be administered and discovery obtained and oral evidence and cross-examination of a deponent on his affidavit were made more accessible. But no new substantive remedy was provided, except the power in Rule 9(4), when certiorari was sought, to remit the matter to the lower deciding authority. This power was confirmed by section 31(5) of the Supreme Court Act 1981. Of course, the changes encouraged the use of judicial review because the new procedure provided a more effective way of reaching the goal. I refer my readers to Lord Denning's observation in the Court of Appeal reported in O'Reilly v. Mackman $^{45}$ and to Lord Diplock's in the same case. ${ }^{46}$ The 1977 innovations followed recommendations by the Law Commission.

Almost the same reforms were discussed in the Report of the Committee on the Supreme Court of Judicature of Northern Ireland (1970 Cmnd 4292, paragraphs 103-116) and these came to fruition in the Judicature (Northern Ireland) Act 1978 , ss. 18-25 and a new Order 53 which came into operation on 1st January, 1981.

Apart from the new procedural advantages, a homely way of describing the change is to say that, except for your section 31(5) and the new possibilities introduced by our sections 21 and 25 , we started with five golf clubs and can now put them in one bag but we cannot play any shots with them which we could not play before. But there is an atmosphere of change, and that atmosphere has been promoted by the new procedure.

In the Northumberland case Denning L. J. stated. ${ }^{47}$

"It will have been seen that throughout all the cases there is one governing rule: certiorari is only available to quash a decision for error of law if the error appears on the face of the record."

45. [1983] 2 A.C. 237 , at pp.253-256

46. At pp.277-282.

47. At p.351. 
Be it noted that this was said in a case where the lower deciding authority was not a court but a tribunal. Other things have been said more recently which, I feel, must be very deliberately weighed, having regard to Sir Patrick Neill's statement that since 1977 "the flow of decided cases has accelerated at a dizzy pace." If Al Jolson were still here, he might exclaim "You ain't heard nothing yet!"

I can see merit in approaching courts and other deciding authorities differently, so far as legal error mithin jurisdiction is concerned, but you will not expect me to discuss such a big subject in my present context. But, what is very important, no matter how orthodox the proposed remedy, is to decide what constitutes the record. Many of you will be familiar with the helpful discussion of this point by Griffiths L. J. in the Knightsbridge Cromn Court case already mentioned. Here again I would like to reserve my options for the moment. My feeling is that against the benefit conferred by the new light we must set the danger of being encouraged to ransack with a view to upsetting them all kinds of orders and decisions which until recently would have been regarded as invulnerable to attack by certiorari. And, on the question of unreasonableness, we must beware of relaxing the tests propounded by the Court in Wednesbury and by Lord Diplock in CCSU v. Minister for the Civil Service. ${ }^{48}$

Lastly, we might reflect that it is much easier to obtain leave to apply for judicial review than it was to get a conditional order to quash. This, too, may have had an influence on some final orders which have been granted recently.

\section{Conclusion}

Now let me try to sum up. You will have seen how easy it is, however apolitically one sets sail, to be engulfed in a whirlpool of politics. Indeed that has ceased to be a novel danger in this country. Therefore one needs plenty of ballast and ought to cultivate that preference which the late Lord Justice Harman expressed ${ }^{49}$ for an upright posture.

In his thoughtful and valuable collection of essays entitled The $7 u d g e^{50}$ Lord Devlin, discussing the Aequum et Bonum, the concept of justice according to the merits, as distinct from justice according to law, had this to say, ${ }^{51}$

"In the first place, justice according to law by imposing a norm also secures it. Against the number of cases in which the law hinders the good judge from expressing the aequum et bonum, there must be put the number in which it prevents the bad judge from giving effect to idiosyncratic notions. For most of the law's history the public has looked upon it as a protection against corrupt or stupid judges. When the public thinks of the law as obstructive, it is a high mark of confidence in the judiciary.

48. [1985] A.C. $374,410 \mathrm{G}$.

49. In Re Goldschmidt [1957] 1 All E.R. 513, at p.514.

50. O.U.P. 1979.

51. Op. cit. at p.88. 
Akin to this consideration is the thought that the law is a protection for the judges themselves. For the law does and ought to embody the collective wisdom. No judge who applies it can be accused of partiality. A judge who has to reach his conclusion without its guidance or who feels sufficiently confident to reject the guidance puts his personal reputation at stake."

More recently Lord McCluskey in his inspiring Reith lectures has said:

"Law which is uncertain is bad in principle, even if the results in particular cases can be justified. When longstanding rules can be abandoned, when too many cases divide judicial opinion and can be decided either way, then the warning signals should be out."

He further observed that in the law avoidable uncertainty is an evil, and unfettered judicial freedom of choice a vice.

Let me hark back to Liversidge v. Anderson, ${ }^{52}$ not for the purpose of challenging anything said in Landmarks in the Law, that splendid book by my much loved and admired friend Lord Denning, but in order to draw a moral. If there is a conflict between expediency and strict law, let the conflict be recognised, and if the law ought to be changed by Parliament, then let it be changed - and the sooner the better.

Some of the lessons I have learnt (but one's education is never complete) are the following:

1. The courts must be seen to act independently of the Executive and not to be its servants and agents.

2. The courts should not make policy, particularly in a community where even people of goodwill are not agreed on the social and political means to salvation.

3. Nor must we bend the facts or the law to achieve what looks like a fair result. "Justice" achieved for one side by this method amounts to injustice for the other.

4. The rule of law must be seen to prevail.

Finally, a story of which counsel is not the hero but which illustrates both error on the face of the record and the conflict between law and the safety of the State. About 1949 I was resisting an application to quash a disjunctive conviction and had found an authority in the shape of $R$. (Patterson) v. Tyrone $77^{53}$ decided on 16th November, 1914 (the date is relevant) by a Divisional Court in which Palles C. B. presided. The conviction recorded that the defendants "did unlawfully buy, detain or receive from soldiers or other persons acting on their behalf military property." There are dozens of cases like this, falling almost indiscriminately on either side of the line. The court had held that this conviction was not bad for uncertainty but, when I hopefully tendered my offering, Black L. J. only said, "Stealing military equipment was not a very popular offence during the Retreat from Mons." 